\title{
Comparison of Prostate Volume in Patient Diagnosed with BPH with and without Type 2 Diabetes Mellitus Assessed with Transabdominal Ultrasonography
}

\author{
Lukmana Lokarjana ${ }^{1,2, *}$, Elva Denengsih ${ }^{2}$, Priatna ${ }^{2,3}$, Laila Azra Pratesya ${ }^{2}$ \\ ${ }^{1}$ Department of Surgery, ${ }^{2}$ Faculty of Medicine, ${ }^{3}$ Department of Radiology \\ ${ }^{1,3}$ RS TK II Dustira, ${ }^{2}$ Universitas Jenderal Achmad Yani \\ Cimahi, Indonesia \\ *lukmana.lokarjana@fk.unjani.ac.id
}

\begin{abstract}
Benign Prostatic Hyperplasia (BPH) is the second most common urological disorder encountered in a urology clinic in Indonesia. This disease is commonly found in men over 50 years. one of the risk factors that are thought to influence the occurrence of BPH is diabetes mellitus (DM). The purpose of this study was to determine the relationship of BPH with DM type 2 in Rumah Sakit Dustira. An observational analytic study with cross sectional design conducted at Rumah Sakit Dustira in the 2018-2019. This study involved 19 people with DM and 19 people without DM by consecutive sampling. The research data was obtained from medical records. The results are majority of subjects were $>75$ years $(33.33 \%)$, the mean prostate volume of BPH patients who also had DM was 55 grams and those who did not have DM was 42.67 grams. The analysis showed that there was a significant difference between the prostate volume of BPH patients with type 2 diabetes mellitus and without type 2 diabetes mellitus $(p<0.05)$. It is concluded that there is a significant difference between the prostate volume of BPH patients with type 2 diabetes mellitus and without type 2 diabetes mellitus.
\end{abstract}

Keywords-benign prostatic hyperplasia, diabetes mellitus, prostate volume

\section{INTRODUCTION}

Benign prostatic hyperplasia $(\mathrm{BPH})$ is a non-cancerous enlargement of the prostate gland. This disease is the second most common disorder encountered in Urology Clinics in Indonesia after urinary tract stones. Benign prostate hyperplasia $(\mathrm{BPH})$ is found in more than $50 \%$ of men aged over 50 years. An enlarged prostate gland volume can result in an obstruction in the lower urinary tract. This occurs due to pressure on the urethra where it penetrates the prostate making urination difficult, reducing the strength of the urine flow, or causing urine to drip. With increasing age, there will be changes in the balance of testosterone and estrogen because testosterone production decreases and there is a conversion of testosterone to estrogen in the peripheral adipose tissue. Based on the autopsy, microscopic changes in the prostate can be found at the age of 30- 40 years. When these microscopic changes continue to develop, there will be changes in the anatomical pathology [1].

In Indonesia, benign prostate enlargement is the second most common urological case after urinary tract stones. It is estimated that almost 50 percent of Indonesian men aged over 50 years, with a life expectancy of up to 65 years are found to have BPH. Then, 5 percent of Indonesian men have entered the environment aged over 60 years. Therefore, if seen, from more than 260 million Indonesians, it can be estimated that 130 million are men, and those aged 60 years and over are approximately 5 million, it can be generally stated that approximately 2.6 million Indonesian men suffer from $\mathrm{BPH}$ disease [2]

Also, other risk factors can trigger prostate enlargements, such as diabetes mellitus (DM), dyslipidaemia, obesity, hypertension, and genetics. The increased incidence shows evidence that metabolic disorders increase the risk of developing benign prostatic hyperplasia [3] be assessed in several ways. Among them by measuring the cardiothoracic ratio (CTR) on the posteroanterior (PA) and anteroposterior (AP) chest X-ray. If the measurement results are more than 50 percent, the heart is said to be enlarged in the atria or ventricles [4].

Diabetes Mellitus is a metabolic disorder caused by a disruption in the insulin mechanism which causes insulin resistance which causes hyperinsulinemia. This hyperinsulinemia condition causes the Nitric Oxide level to decrease so that it stimulates excessive activation of the sympathetic nerves so that the smooth muscle in the prostate gland experiences excessive contractions which will cause a Lower Urinary Tract Symptom consists of obstruction (voiding symptoms), irritation, and post-urinary symptoms. Symptoms of obstruction include weak and intermittent urinary tract, feeling dissatisfied after urinating. Symptoms of irritation include increased urinary frequency, urgency, nocturia. Postvoiding symptoms include dripping urine (dribbling) to the most severe symptom is urine resistance [5]. 
The presence of an enlarged prostate gland will cause an increase in resistance in the bladder neck and prostate area as well as thickening of the detrusor muscle. This overtime will lead to hydroureter, hydronephrosis, and kidney failure. In more advanced complications, haematuria can be found on urine examination. If there is haematuria, other causes must be taken into accounts, such as malignancy of the urinary tract, stones, and urinary tract infections, although BPH itself can cause haematuria. Haematuria in BPH patients usually occurs if there has been an infection in the urinary tract or the formation of sediment stones in the bladder.

Determination of prostate volume is very useful for planning therapy and monitoring the results of therapy of Benign prostate hyperplasia. Determination of prostate volume can be done by digital rectal examination, ultrasonography (USG), Magnetic Resonance Imaging (MRI), Computed Tomography (CT). Although a digital rectal examination is the standard test for assessing prostate size, it is inaccurate and subjective. MRI and CT can accurately measure prostate volume, but this examination requires a higher cost. Ultrasound is a more useful examination to determine the degree of prostate enlargement accurately, one of which is the Transabdominal Ultrasound (TAUS) which can detect hydronephrosis or kidney damage due to prolonged $\mathrm{BPH}$ obstruction.

\section{METHODS}

The research design used was cross-sectional research using recorded data medical analysis on a comparative basis. To determine the comparison of the prostate volume of $\mathrm{BPH}$ patients with and without type 2 diabetes mellitus using Transabdominal Ultrasonography at Dustira Hospital for the period 2018-2019. The object of the study used medical record data of all benign prostate hyperplasia patients at Dustira Hospital who were included in the inclusion criteria. Collecting data in the study using notes or medical records which were the samples of the study. The sampling technique in this study used a consecutive sampling technique where all data that met the sampling criteria were included in the study until they met the specified number of samples.

The research was conducted at the Dustira Hospital in November-January 2020. The data used in this study were secondary in the form of medical records of patients who went to Dustira Cimahi Hospital. The study was conducted on patients with Benign Prostatic Hyperplasia. The total number of research samples was 36 people who fit the inclusion criteria of the study, namely $18 \mathrm{BPH}$ patients with Type $2 \mathrm{DM}$ and 18 BPH patients without Type $2 \mathrm{DM}$.

\section{RESULTS AND DISCUSSION}

TABLE I. FREQUENCY DISTRIBUTION OF GENERAL CHARACTERISTICS OF RESEARCH SUBJECTS BY GENDER.

\begin{tabular}{|l|l|l|}
\hline Variable & Frequency & Percentage \\
\hline Age (years old) \\
\hline $50-54$ & 1 & 2,78 \\
\hline $55-59$ & 6 & 16,67 \\
\hline $60-64$ & 5 & 13,89 \\
\hline $65-69$ & 6 & 16,67 \\
\hline $70-74$ & 6 & 16,67 \\
\hline$>75$ & 12 & 33,33 \\
\hline
\end{tabular}

Based on Table 1, it can be seen that in the BPH group with Type 2 DM and Without Type 2 DM, at the age of 50-54 years there was 1 person $(2.78 \%)$, at the age of $55-59$ years there were 6 people $(16.67 \%)$, at the age of $60-64$ years there were 5 people $(13.89 \%)$, at the age of $65-69$ there were 6 people (16.67), at the age of 70-74 years there were 6 people $(16.67 \%)$, aged $>75$ years as many as 12 people (33.33). Most respondents are in the age group above 75 years, as many as 12 people $(33.33 \%)$.

These results are in line with a study conducted by Wulandari in 2018 in Yogyakarta. This quasi-experimental study involving 30 patients, the majority of research subjects, were $>65$ years old [6]. Similar results were also shown by research conducted by Adha in 2018 which was conducted in Lampung. Research with this case-control design, the average age of the research subjects is 66 years. Another study that also shows the result in line with this is a study conducted by Ruspanah in 2017 in Ambon. Research with a cross-sectional design involving 239 this person found that the majority of the study subjects were $>65$ years old. The results of the study show that as you age, the prevalence of BPH will increase. This is consistent with the pathogenesis of BPH which is closely related to age. In elderly men, there is a process of remodelling the tissues in the prostate gland, especially in the transitional zone. The pathology of the prostate gland associated with increasing age is through an imbalance between the hormones estrogen and testosterone, the interaction between stroma-epithelial cells, and growth factors that trigger the growth of prostate gland cells.

TABLE II. PROSTATE VOLUME CHARACTERISTICS OF BPH PATIENTS WITH OR WITHOUT TYPE 2 DM AT DUSTIRA HOSPITAL

\begin{tabular}{|l|l|l|l|l|}
\hline Group & Mean & Deviation St. & Median & Min - Max \\
\hline DM & 55.00 & 18.47 & 50 & $32-88$ \\
\hline Non-DM & 42.67 & 14.63 & 40 & $24-83$ \\
\hline
\end{tabular}

Table 2 shows that the mean prostate volume of patients with BPH who also experienced diabetes 55 grams and those was who did not experience diabetes were 42.67 grams.

The analysis showed that there was a significant difference between the prostate volume of $\mathrm{BPH}$ patients with type 2 
diabetes mellitus and without type II diabetes mellitus ( $p$ $<0.05)$. These results are in line with research conducted by Ozcan in 2017. This case-control study found that there was a positive correlation between prostate volume and the diagnosis of type 2 diabetes mellitus in BPH patients [7]. Similar results were also shown by a study with a population of Indonesians conducted by Sari in 2016. This cohort study involving 118 $\mathrm{BPH}$ patients concluded that BPH patients with DM had a greater prostate volume than BPH without DM [8].

Different results were obtained in a study conducted by Hakim in 2018. The study with a case-control design involving 62 people found that there was no significant difference between the prostate volume of BPH patients who had type 2 diabetes and those who did not experience type 2 diabetes. Presumably due to an imbalance between the number of case groups and control groups in Hakim's study in 2018. The study used 11 diabetic patients and 51 non-diabetic patients. This imbalance is thought to affect the results of the study.

TABLE III. XANALYSIS RESULTS WITH PRostate Volume Bound VARIABLES

\begin{tabular}{|l|l|l|c|l|}
\hline Group & Mean & Deviation St. & $\boldsymbol{\alpha}$ & $\boldsymbol{p}$-score \\
\hline DM & 55.00 & 18.47 & 0,05 & 0,041 \\
\hline Non DM & 42.67 & 14.63 & & \\
\hline
\end{tabular}

Table 3 shows that there is a significant difference between the prostate volume of BPH patients with type 2 diabetes mellitus and without type 2 diabetes mellitus ( $p<0.05)$. Diabetes mellitus type 2 is a metabolic disorder characterized by hyperglycaemia or high blood glucose levels and insulin resistance. Increased levels of insulin in the body affect the growth of the prostate gland through activation of IGF signals, hormonal changes, and increased conversion of testosterone to DHT which can stimulate prostate gland cell proliferation.

\section{CONCLUSION}

Based on the results of research conducted by researchers, it can be concluded that of the 36 respondents who suffered from BPH, the highest age group over 75 was 12 people $(33.33 \%)$. The mean prostate volume of BPH patients who had type 2 diabetes mellitus was 55 grams. The mean prostate volume of BPH patients who did not have type 2 diabetes mellitus was 42.67 grams. There is a significant difference between the prostate volume of $\mathrm{BPH}$ patients with type 2 diabetes mellitus and without type 2 diabetes mellitus.

\section{REFERENCES}

[1] C. Corwin, Buku Saku Patifiologi Sistem Reproduksi. Jakarta: EGC, 2009.

[2] R. Goyal, D. Dubey, A. Mandhani, A. Srivastava, R. Kapoor and A. Kumar, "Uroflowmetry, trans rectal ultra sonography and power doppler to develop a less invasive bladder outlet obstruction score in benign prostatic hyperplasia: A prospective analysis," Indian Journal of Urology, vol. 22, no. (2), pp. 125, 2006.

[3] C. Chasani, Buku Ajar Ilmu Penyakit Dalam: Hipertrofi Prostat Jinak. Jakarta: Interna Publishing, 2014.

[4] A. Masjoer, Kapita Selekta Kedokteran. Jakarta: Media Aesculapius FKUI, 2009.

[5] B. Purnomo. Dasar-dasar Urologi. Jakarta: Sagung Seto, 2011.

[6] A. Wulandari, L.N. Asnindari and R.F. Kafil, Pengaruh Mobilisasi Din Terhadap Nyeri Post Operasi TURP Pada Pasien BPH Di RSU PKU Muhammadiyah Bantul, 2018.

[7] L. Ozcan, H. Besiroglu, M. Dursun, C.E. Polat, A. Otunctemur and E. Ozbek, "Comparison of the clinical parameters of benign prostate hyperplasia in diabetic and non diabetic patients," Archivio Italiano di Urologia e Andrologia, vol. 89, no. (1), pp. 26-30, 2017.

[8] A. Sari, Perbandingan Volume Prostat Antara Pasien Benign Prostate Hyperplasia Dengan Diabetes Mellitus Dan Tanpa Diabetes Mellitus Di Rsud Dr. Moewardi Surakarta. Surakarta: Skripsi, 2016. 